\title{
Haemato-biochemical studies of Camels infested with Trypanosomiasis
}

\author{
K. Padmaja \\ Department of Clinical Veterinary Medicine, \\ College of Veterinary Science, Rajendranagar, Hyderabad-500 030, Andhra Pradesh, India \\ E-mail: satyaja35@yahoo.co.in \\ Received: 17-10-2011, Accepted: 21-11-2011, Published Online: 10-03-2012 \\ doi: $10.5455 /$ vetworld.2012.356-358
}

\begin{abstract}
Aim: To know the Haemato-Biochemical values of camels infested with Trypanosomiasis.

Materials and Methods: A herd of 13 camels showing signs of inappetance, lethargy, going down in condition, urticarial swellings, oedema of pads and occasional shivering were examined. Blood samples were collected to screen for the trypanosomes and to record hemato-biochemical alterations. Treatment of both group I and group II was undertaken.

Results: Nine camels were positive for Trypanosomes recording an incidence of $69.23 \%$. A significant $(\mathrm{P}<0.01)$ increase in temperature and decrease in TEC was observed, while a significant $(\mathrm{P}<0.05)$ increase in TLC, neutrophils and eosinophils and significant $(\mathrm{P}<0.05)$ decrease in lymphocytes was noted in positive blood samples. Significant $(\mathrm{P}<0.05)$ decrease in blood glucose levels was recorded and one camel died due to hypoglycemic encephalopathy. Trypanosomiasis was treated successfully with Quinapyramine salts.
\end{abstract}

Keywords: Biochemical, Camels, Hematological, Incidence, Therapy, Trypanosomiasis,

\section{To cite this article:}

Padmaja K (2012). Haemato-Biochemical studies and Therapy of Trypanosomiasis in Camels, Vet. World 5(6): 356-358, doi: 10.5455/vetworld.2012.356-358

\section{Introduction}

Trypanosomiasis (surra) is a chronic disease in camels and characterized by remittent fever, anaemia and cachexia [1]. It is caused by flagellate protozoan, Trypanosoma evansi and mechanically transmitted by biting flies such as Tabanus, Stomoxys and Liperosia [2]. Trypanosoma evansi is the most widely distributed pathogenic animal trypanosome, affecting domesticated livestock in Asia, Africa, Central and South America and Europe [3]. It causes a widely prevalent serious disease of domestic and wild animals which is of considerable economic importance in the Indian subcontinent [4] and South Asian countries [5]. An acute form characterized by persistent fever with trypanosomes always demonstrable in peripheral blood circulation and ending fatally after a few weeks [6]. In Hyderabad, where the present work was undertaken, the camel population is very less. A few camels are reared in the city for joy rides and ceremonial processions.

In the present investigation, a herd of 13 camels showing signs of inappetance, lethargy, going down in condition, urticarial swellings, oedema of pads and occasional shivering were studied with an objective of screening for trypanosomes and haemato-biochemical alterations.

\section{Materials and Methods}

The herd of 13 camels was examined for clinical signs and temperatures were recorded. To screen for the presence of trypanosomes and to study haematobiochemical alterations, blood was collected from jugular vein as per International Animal Ethics Committee Guideline. Wet smears were collected and screened under high power for the presence of trypanosomes [7]. Whole blood was collected in the vials containing Ethylene diamine tetra acetic acid (EDTA) and without anti coagulant for haematological and blood glucose estimation respectively. Camels were divided into two groups. Group I positive for trypanosomes and group II negative for trypanosomes.

The total erythrocyte count (TEC), total leucocyte count (TLC), haemoglobin (Hb), packed cell volume (PCV) and differential leucocyte count (DLC) were estimated as per the methods described by Schalm et al. [8]. The glucose levels were estimated immediately as per the method of Folin and $\mathrm{Wu}$ [9]. The haematobiochemical alterations of both the groups were statistically analyzed by employing't' test [10].

Therapy was instituted with quinapyramine prosalt @ $5 \mathrm{mg} / \mathrm{kg} \mathrm{b} \mathrm{wt} \mathrm{and} 2.5 \mathrm{mg} / \mathrm{kg}$ b. wt subcutaneously single dose in group I and group II 
Haemato-Biochemical studies and Therapy of Trypanosomiasis in Camels

Table-1. Mean clinical and hemato-biochemical values of camels

\begin{tabular}{llccc}
\hline Sr. No. & Parameter & Normal values & Group I (Positive for Tryps) & G roup II (Negative for Tryps) \\
\hline 1 & Temp $\left({ }^{\circ} \mathrm{F}\right)$ & $99.00 \pm 1.0$ & $102.7 \pm 0.56^{* *}$ & $99.5 \pm 0.32$ \\
2 & TEC $\left(10^{6} \mathrm{cmm}\right)$ & $7.20 \pm 0.08$ & $4.4 \pm 0.34^{* *}$ & $7.0 \pm 0.26$ \\
3 & TLC $\left(10^{3} \mathrm{cmm}\right)$ & $12.50 \pm 0.88$ & $20.4 \pm 0.70^{*}$ & $15.4 \pm 1.82$ \\
4 & Hb $(\mathrm{gm} \%)$ & $13.20 \pm 0.81$ & $8.6 \pm 0.31^{*}$ & $10.3 \pm 0.63$ \\
5 & PCV & $43.00 \pm 1.10$ & $25.6 \pm 1.09^{*}$ & $32.5 \pm 2.63$ \\
6 & Neutrophils & $30.57 \pm 1.16$ & $41.8 \pm 2.04^{*}$ & $34.3 \pm 1.31$ \\
7 & Lymphocytes & $63.00 \pm 2.12$ & $42.7 \pm 3.31^{*}$ & $53.0 \pm 3.14$ \\
8 & Monocytes & $2.40 \pm 0.32$ & $4.2 \pm 0.46$ & $4.8 \pm 0.48$ \\
9 & Eosinophils & $2.20 \pm 0.04$ & $8.9 \pm 1.37^{*}$ & $4.3 \pm 1.31$ \\
10 & Basophils & $0.70 \pm 0.01$ & $1.3 \pm 0.37$ & $1.3 \pm 0.25$ \\
11 & Blood Glucose $(\mathrm{gm} / \mathrm{dL})$ & $80.00 \pm 2.22$ & $63.6 \pm 5.72^{*}$ & $82.0 \pm 2.16$ \\
\hline
\end{tabular}

$* * \mathrm{P}<0.01 \quad * \mathrm{P}<0.05$

animals, respectively. Supportive therapy was undertaken with $20 \%$ dextrose, $1000 \mathrm{ml}$, intravenous for two days and Inj. B-Complex with liver extract, 15 $\mathrm{ml}$, intramuscularly for 3 days in group I animals, while group II animals received Inj. B-complex with liver extract, $15 \mathrm{ml}$, intramuscularly for 3 days

\section{Results and Discussion}

The herd improved and returned to normal health within a week after treatment.

The herd of 13 camels showed the clinical signs of inappetance, lethargy, going down in condition, urtricarial swellings, oedema of pads, abdomen and sheaths with occasional shivering. Similar signs were reported by Mottelib et al. [11] in camels suffering with trypanosomiasis. Out of 13 camels examined, 9 were positive for trypanosomes (group I) and 4 animals were negatve (gPtlup II) on wet smedr exafpF recording an incidence of $69.23 \%$ as against $14.28 \%$ recorded by Mahajan [12] in Hyderabad state. While an incidence of $7.50 \%, 10.67 \%$ and $13.72 \%$ were reported by Pathak [13], Chaudhary and Iqbal [14] and Shah et al. [15] respectively. Camel acts as a carrier with frequent crises and parasitemia denotes acute infection of the disease [11].

Group I animals recorded a significant $(\mathrm{P}<0.01)$ increase in temperature and significant $(\mathrm{P}<0.01)$ decrease of TEC. A significant $(\mathrm{P}<0.05)$ decrease of $\mathrm{Hb}$ and $\mathrm{PCV}$ in positive animals was recorded which indicated anaemia (Table 1) which can be attributed to haemolytic factor produced by trypanosomes [6]. The present findings are in accordance with Derakhshanfar, et al [16].

Leucogram showed a significant $(\mathrm{P}<0.05)$ decrease of lymphocytes indicating immune suppression [14] as against lymphocytosis indicating chronic infection was reported by Derakhshanfar,et al [16]. A significant $(\mathrm{P}<0.05)$ increase in TLC, neutrophils and eosinophils was observed. These changes can be attributed to an increase in the activity of the mononuclear phagocytic system. The eosinophilia observed is a feature of parasitic infections and is associated with immediate type hyper sensitivity reactions [6]. However, an insignificant decrease and increase in TEC, Hb, PCV, leucogram and neutrophils respectively, was recorded while a significant increase in eosinophils was reported by Ahmad et al [17] in haemoparasitized camels.

Group I animals showed significant $(\mathrm{P}<0.05)$ decrease in blood glucose and one animal died showing signs of circling, head pressing and convulsions with blood glucose of $20 \mathrm{mg} / 100 \mathrm{ml}$. The nervous signs in camel can be attributed to hypoglycemic encephalopathy. Hypoglycemia can be attributed to malfunctions of adrenals, pancreas and thyroid glands [18].

Camel trypanosomiasis is a disease of major economic importance and control is limited to treating those animals that are considered to be infected on the basis of clinical signs and wet blood smears and prophylactic therapy to the rest of the herd.

\section{Acknowledgements}

The author is thankful to the staff of Veterinary Biological Research Institute (VBRI), Animal Husbandry Department, Hyderabad for the laboratory support extended during the study.

\section{Competing interests} interests.

The authors declare that they have no competing

\section{References}

1. Gill, B.S. (1991). Trypanosomes and Trypanosomiases of Indian Livestock, Indian Council of Agricultural Research, New Delhi.

2. Soulsby, E.J.L. (1968). Helminths, Arthropods and Protozoa of Domesticated Animals. 6th Edn. The 
English Language Book Society \& Bailliere, Tindal and Cassell Ltd., London.

3. Salim, B., Mohammed, A.B., Joseph, K., Ichiro, N. and Chihiro, S.(2011). Molecular epidemiology of camel trypanosomiasis based on ITS1 rDNA and RoTat 1.2 VSG gene in the Sudan. Parasites and Vectors 4:31.

4. Sood, N.K., Singla, L.D., Singh, R.S. and Uppal, S.K (2011). Association of Trypanosoma theileri with peritonitis in a pregnant cross-bred cow: a case report. Veterinarni Medicina 56(2):82-84.

5. Konnai, S., Mekata, H., Mingala, C.N., Abes, N.S., Gutierrez, C.A., Herrera, J.R., Dargantes, A.P., Witola, W.H., Cruz, L.C., Inoue, N., Onuma, M. and Ohashi, K.(2009). Development and application of a quantitative real-time PCR for the diagnosis of Surra in water buffaloes. Infection, Genetics and Evolution. 9, 449-452.

6. Enwezor, F.N.C. and Sackey, A.K.B. (2005). Camel trypanosomosis - a review. Veterinarski Arhiv 75 (5): 439-452.

7. Bhutto, B., Gadahi, J.A., Shah, G., Dewani, P. and Arijo A.G. (2009). Field investigation on the prevalence of Trypanosomiasis in Camels in Relation to Sex, Age, Breed and Herd Size. Pak. Vet. J, 30(3):175-177.

8. Schalm, O.W., Jain, N.C., and Carrol, E.J. (1986). Veterinary Haematology, 4th Edn, Lea and Febiger, Philadelphia.

9. Folin, O. and Wu, H. (1920). A system of blood analysis: A simplified and improved method for determination of sugar. Journal of Biological chemistry 41:367-373.

10. Snedecor, G.W. and Cochran, W.G. (1994). Statistical
Methods, 8th Edn., East West Press Pvt Ltd., New Delhi, India.

11. Mottelib, A.A., Hosein, H.I., Mourad, I., El-Sherif, A.M. and Abo-Zeid, A.S.I. (2005). Comparative evaluation of various diagnostic techniques for trypanosome evansi in naturally infected camels. ISAH 2005- Warsaw, Poland 2:505-507.

12. Mahajan, M.R. (1939). Indian Journal of Veterinary Science 15:277 as cited by Vashishta, M.S. and Singh, R.P. (1977). In: Protozoal diseases. In: Camel diseases in India, Scientific Book Agency, Calcutta.

13. Pathak, K.M., Arora, J.K. and Kapoor, M. (1993). Camel trypanosomosis in Rajasthan, Indian Vet. Parasitol, 49(2-4):3 19-23.

14. Chaudhary, Z.I. and Iqbal, J. (2000). Incidence, biochemical and haematological alterations induced by natural trypanosomosis in racing dromedary camels. Acta Tropica 77(2):209-213.

15. Shah, S.R., Phulan, M.S., Memon, M.A., Rind, R. and Bhatti, W.M. (2004). Trypanosomes infection in camels. Pakistan Vet. J., 24(4):209-210.

16. Derakhshanfar, A., Mozaffari, A. A. and Mohaghegh Zadeh, A. (2010). An Outbreak of Trypanosomiasis (Surra) in Camels in the Southern Fars Province of Iran: Clinical, Hematological and Pathological Findings. Research Journal of Parasitology 5(1): 2326.

17. Ahmad,S.,Butt, A.A., Muhammad, G., Athar, M. and Khan, M.Z.(2004). Haematobiochemical Studies on the Haemoparasitized Camels. Int.J. Agri. Biol.6 (2)331-334

18. Narladkar, B.W. (2005-06). Trypanosomosis in animals - a disease of concern - review article, http://ah.adfmaharashtra.in/pdf/dis/. 